\title{
СУПЕРЕЧНОСТІ ДЕМОКРАТИЧНОЇ МОДЕРНІЗАЦІЇ УКРАЇНСЬКОГО СУСПІЛЬСТВА ЯК ДЖЕРЕЛА ПОСИЛЕННЯ СОЦІАЛЬНОӤ НАПРУЖЕНОСТІ
}

УДК 316. 47

Судаков Володимир Іванович

доктор соиіологічних наук, професор, Київський національний університет імені Тараса Шевченка,

Київ, Україна, vl_sudakov@ukr.net

\section{СУПЕРЕЧНОСТІ ДЕМОКРАТИЧНОЇ МОДЕРНІЗАЦЇ̈ УКРАЇНСЬКОГО СУСПІЛЬСТВА ЯК ДЖЕРЕЛА ПОСИЛЕННЯ СОЦІАЛЬНОЇ НАПРУЖЕНОСТІ}

Стаття, у відповідності до поставленої мети, присвячена дослідженню суперечностей політичних детермінант соціальної напруженості як специфічних джерел іiі посилення в сучасному українському суспільстві. Концептуальна позиція автора, стосовно змісту визначеної проблеми дослідження, представлена в наступних висновках. Зокрема, звернуто увагу на труднощі реформування політичної системи України, наслідком чого стала деформація політичної свідомості громадян та зростаюча політична корупція. Аргументовано, що за основними параметрами своєї соціальної ідентифікації сучасне українське суспільство є пострадянським, демократична модернізація якого відбувається стихійно i непослідовно. Нинішня політична влада України підтримує консервативний сценарій демократичних перетворень, наслідком чого стало відтворення застарілих функціональних режимів політичної системи, внаслідок чого більшість громадян України знаходяться у стані амбівалентності по відношенню до політичних інститутів, легальність яких не підкріплена ні правом, ні мораллю. Емпіричні дані репрезентативних моніторингових соціологічних досліджень засвідчують, що переважна більшість населення по відношенню до процесу демократичних перетворень в Україні знаходиться у стані пасивності та не вірить у їх успіх. Саме тому в Україні сформувалися і стабільно відтворюються практики політичної участі громадяни, які реально $\epsilon$ соціальним джерелом політичної корупції. 3'ясовано, що важливим чинниками посилення соціальної напруженості в українському суспільстві є невизначеність політичної стратегії вирішення двох взаємопов'язаних фундаментальних проблем: 1) територіальної цілісності України та 2) пї соціальної цілісності. Існуюча глобальна конкуренція та реальна функціональність онтологічних чинників дезорганізації соціального порядку, таких як соціальна недовіра, корупція, депривація, збройні конфлікти та терористичні акції на даний час $\epsilon$ перешкодами соціальної та політичної консолідації сучасного українського суспільства. 
Ключові слова: соціальна напруженість, українське суспільство, політичної система, політичні реформи, політична корупція.

Sudakov Volodymyr, Sc. D. of Sociology, Professor, Kyiv Taras Shevchenko National University, Kyiv, Ukraine

Contradictions of democratic modernization of the Ukrainian society as the sources to enhancing social tensions

The article, in accordance to its main purpose, is devoted to the research of the contradictions of the social tensions political determinants as the specific sources of the strengthening in the contemporary Ukrainian society. The author's conceptual point of view towards the problem under research is presented in the following scientific conclusions. It is estimated that difficulties of the national political system reformation has led to the citizens political consciousness deformation and a political corruption increase. It is argued that, the contemporary Ukrainian society, according to the basic parameters of its social identification, is a post-Soviet society with a democratic modernization being spontaneous and inconsistent. Today a political power of Ukraine supports the conservative scenario of democratic reforms, resulting in the resumption of the obsolete political system functional regimes, with the majority of the Ukrainian citizens being in a state of ambivalence regerding political institutions legality of which is neither supported by law nor morality. Empirical data of the sociological survays representative monitoring indicate the overwhelming majority of the population in relation to the democratic reforms process in Ukraine to be in a state of passivity not believing in their success. That is why Ukraine has formed and is consistently reproducing the political participation practices of the citizens being a real social source of the political corruption. It was found out that an important factor of the Ukrainian society social tension strengthening to be the uncertainty of the political strategy of the two interrelated fundamental problems solving: 1) the territorial integrity of Ukraine and 2) its social integrity. The existing global competition and the real functionality of the social order disorganization ontological factors, such as a social mistrust, corruption, deprivation, armed conflicts, and terrorist actions are the current obstacles to the social and political consolidation of the contemporary Ukrainian society.

Key words: social tension, Ukrainian society, political system, political reforms, political corruption.

Судаков Владимир Иванович, доктор сочиилогических наук, профессор, Киевский национальный университет имени Тараса Шевченко, Киев, Украина

Противоречия демократической модернизации украинской общества как источники усиления социальной напряженности 


\section{СУПЕРЕЧНОСТІ ДЕМОКРАТИЧНОЇ МОДЕРНІЗАЦЇ̈ УКРАЇНСЬКОГО СУСПІЛЬСТВА ЯК ДЖЕРЕЛА ПОСИЛЕННЯ СОЦІАЛЬНОЇ НАПРУЖЕНОСТІ}

Статья, в соответствии с поставленной целью, посвящена исследованию противоречий политических детерминант социальной напряженности как специфических источников ее усиления в современном украинском обществе. Концептуальная позиция автора, относительно содержания проблемы данного исследования, представлена в следующих выводах. В частности, обращено внимание на трудности реформирования политической системы Украины, следствием чего стала деформация политического сознания граждан и растущая политическая коррупция. Аргументировано, что по основным параметрам своей социальной идентификации современное украинское общество является постсоветским, демократическая модернизация которого происходит стихийно и непоследовательно. Нынешняя политическая власть Украины поддерживает консервативный сценарий демократических преобразований, следствием чего стало воспроизводство устаревших функциональных режимов политической системы, в результате чего большинство граждан Украины находятся в состоянии амбивалентности по отношению к политическим институтам, легальность которых не подкреплена ни правом ни моралью. Эмпирические данные репрезентативных мониторинговых социологических исследований показывают, что подавляющее большинство населения по отношению к процессу демократических преобразований в Украине находится в состоянии пассивности и не верит в их успех. Именно поэтому в Украине сформировались и стабильно воспроизводятся практики политического участия граждане, которые реально являются социальным источником политической коррупции. Выяснено, что важным факторами усиления социальной напряженности в украинском обществе является неопределенность политической стратегии решения двух взаимосвязанных фундаментальных проблем: 1) территориальной целостности Украины и 2) ее социальной целостности. Существующая глобальная конкуренция и реальная функциональность онтологических факторов дезорганизации социального порядка, таких как социальное недоверие, коррупция, депривация, вооруженные конфликты и террористические акции в настоящее время являются препятствиями социально и политической консолидации современного украинского общества.

Ключевые слова: социальная напряженность, украинское общество, политическая система, политические реформы, политическая коррупция.

Вступ. Сучасний період розвитку більшості країн світу характеризується вченими, політиками та лідерами громадської думки як період складних трансформаційних процесів, обумовлених також нагальними завданнями пошуку оптимальних шляхів гуманізації та демократизації соціальних відносин у різних регіонах планети. 


\section{СУПЕРЕЧНОСТІ ДЕМОКРАТИЧНОЇ МОДЕРНІЗАЦІЇ УКРАЇНСЬКОГО СУСПІЛЬСТВА ЯК ДЖЕРЕЛА ПОСИЛЕННЯ СОЦІАЛЬНОЇ НАПРУЖЕНОСТІ}

Аналіз останніх досліджень і публікацій. Важливо підкреслити, що в розвинутих країнах усталеної демократії зараз ведеться інтенсивний науковий пошук, спрямований на оптимальну адаптацію існуючих моделей демократичної організації соціального порядку до глобальних тенденцій інтернаціоналізації суспільного життя, зростаючого ресурсного впливу транснаціональних компаній, поглиблення соціальних нерівностей між країнами світу, кризи глобального ринку праці та зайнятості, посилення неконтрольованої міжнародної міграції та ін. Водночас, слід констатувати, що основні результати наукового аналізу трансформаційних змін українського суспільства, здійсненого у працях І. Бекешкіної, Є. Головахи, А. Горбачика, А. Єрмолаєва, О. Злобіної, О. Куценко, В. Лапіної, І. Мартинюка, М. Михальченка, В. Паніотто, О. Рєзніка, О. Рудика, Ю. Савельєва, Є. Сірого, В. Танчера, М. Шульги та ін. засвідчили, що характерною ознакою теперішнього часу стала тенденція посилення соціальної напруженості, соціальна драматургія якої наочно проявилася в протестних формах масової поведінки громадян [5, с. 6-54; 4, с. 38-66].

Слід констатувати, на даний час соціологами повною мірою усвідомлена актуальність наукового вивчення онтологічної специфіки соціальної напруженості як атрибутивного явища та процесу суспільного життя. Водночас важливо зазначити, що основні пізнавальні труднощі досліджень феноменальних та процесуальних рис соціальної напруженості можна пояснити складним характером взаємозв'язку специфічних суперечностей соціальної інтеграції, депривації та соціального відторгнення як чинників глобальної трансформаційної динаміки.

Вочевидь, важливо також враховувати, що події та реформаторські зміни, які пов'язані в Помаранчевою революцію та Революцією Гідності на даний час суттєво актуалізували потреби в науковому вивченні специфіки політичних детермінант соціальної напруженості. У даному зв'язку не менш важливим $є$ також і пошук змістовних відповідей на важливе питання: чи реально відбулася якісна трансформація українського суспільства, чи має воно шанси демократичного розвитку та подолання існуючих кризових явищ?

Приймаючи до уваги зазначені обставини, мета даної праці полягає в дослідженні суперечливого характеру політичних детермінант соціальної напруженості як специфічних джерел іiі посилення в українському и суспільстві.

Виклад основного матеріалу. Запроваджені в Україні за роки незалежності ринкові реформи національної економіки, лібералізація та демократизація суспільного життя, реалізація стратегії європейської інтеграції стають визначальними стимулами структурної трансформації українського суспільства. Однак, слід також вказати, що у більшості наукових соціологічних досліджень українське суспільство визначалося як «пострадянське», «постсоціалістичне», «посткомуністичне» 3 неясною історичною долею його 


\section{СУПЕРЕЧНОСТІ ДЕМОКРАТИЧНОЇ МОДЕРНІЗАЦІЇ УКРАЇНСЬКОГО СУСПІЛЬСТВА ЯК ДЖЕРЕЛА ПОСИЛЕННЯ СОЦІАЛЬНОЇ НАПРУЖЕНОСТІ}

демократичного транзиту. Розпочаті владними інститутами України демократичні реформи, на думку багатьох вчених, взагалі не можна вважати надійною гарантією успішних демократичних перетворень у силу їх різновекторної стратегічної спрямованості - стабілізація економічної системи і консервація адміністративних методів управління економічним розвитком та прискорена модернізація політичної системи без належної консолідації політичної еліти.

Наведемо приклад доволі примітної узагальнюючої констатації сер. 90-х рр. минулого століття: «Українське суспільство в політичній проекції дуже далеке від класичних моделей. По-перше, воно не «по-західному», не класично розколото на лівий і правий фланги та центр. Іноді ліві виступають як консерватори, а праві - як прогресисти. Центр не завжди є центром. Адже він змінює свої орієнтації то ліворуч, то праворуч, або просто виконує замовлення «сильних світу цього». По-друге, декларації лідерів та їхні практичні дії нерідко різко розходяться. По-третє, у масовій свідомості влада дедалі більше викликає недовіру, а іiі дії зустрічають прихований спротив, що виявляється у різних формах. Тому сама влада є джерелом напруженості, яке зростає в міру зростання недовіри до неї та до іiі дій. Це свідчить про зростання саморуйнуючої діяльності владних структур, про цілу серію перманентних криз у взаємовідносинах органів влади в трикутнику «президент - парламент - уряд» та між населенням та владою» [3, с. 177].

Важливо звернути увагу, що і в наукових працях самого останнього часу авторитетні вітчизняні соціологи констатують, що українському суспільству скоріш властиве поширення «демократичних ілюзій», ніж тенденція реальної демократизації. Так Є. Головаха, доводить, що на даний час українське суспільство, за своїми базовими онтологічними ознаками, є суспільством «пострадянським» у тому сенсі, що воно і дотепер зберігає сутнісні риси того соціального устрою, від якого громадяни і демократична частина політичної владної еліти намагалися рішуче відмовитися. Аргументація даної позиції загалом базується на доказах, що з перших років незалежності політична влада України обрала консервативний сценарій демократичних перетворень, наслідком чого стало відтворення застарілих соціальних структур та інститутів, ïх стагнація та «шок без терапії». На думку Є. Головахи, у результаті стихійної трансформації «3 відкладеним декларованим транзитом» більшість громадян України знаходяться у стані амбівалентності по відношенню до інституціональних утворень, легальність яких не підкріплена ні правом ні мораллю» [1, с. 15-16].

Варто звернути увагу, що Є. Головаха схильний тлумачити сам феномен «відкладеного декларованого транзиту» як складне соціально-психологічне явище, відтворення якого слід пов'язувати зі зростанням дестабілізаційного 


\section{СУПЕРЕЧНОСТІ ДЕМОКРАТИЧНОЇ МОДЕРНІЗАЦІЇ УКРАЇНСЬКОГО СУСПІЛЬСТВА ЯК ДЖЕРЕЛА ПОСИЛЕННЯ СОЦІАЛЬНОЇ НАПРУЖЕНОСТІ}

потенціалу установок масової свідомості громадян України на соціальний протест, що $є$ одним із найважливіших емпіричних оціночних показників реальних суперечностей демократичних перетворень в Україні.

Слід визнати, що така дослідницька позиція і зараз є перспективною для подальшої наукової розробки, при цьому враховуючи не лише показники дестабілізаційності протестного потенціалу, але й показники цілком функціонально відтворюваних політичних практик громадян, які також виразно відображують радикальні зміни політичної свідомості громадян України в аспектах їх реального небажання бути легітимно діючими суб'єктами демократичних перетворень та розбудови правової держави, а також бути агентами активної протидії корупції в економічній та політичній сферах суспільного життя.

На дану обставину звертає увагу М. Шульга, який у своїх дослідженнях робить цілком конструктивні спроби 3'ясувати причини поширення в Україні «гонорарних політичних практик як форми реалізації соціальних інтересів». Спираючись на емпіричні дані репрезентативних моніторингових досліджень, вчений доводить, що більшість населення по відношенню до процесу демократичних перетворень в Україні знаходиться у стані пасивності та не вірить у їх успіх по причинам «відсутності традиції участі в публічних практиках на основі особистісного вибору» та «розачарування, яке виникло у пересічних громадян на основі новітнього досвіду, отриманого в соціальних практиках, коли їх активні публічні дії не давали ніякого реального результату для них, для реалізації їх соціальних інтересів» [8, с. 116].

Саме тому у населення сформувалися специфічні поведінкові стратегії діяльності, які спрямовані на пряме порушення норм демократичного правопорядку. Так у 2009 р. $88 \%$ опитаних громадян заявили про свою готовність регулярно або вибірково здійснювати протиправні дії корупційного характеру та аморальні вчинки [8, с. 118]. Примітно, що значна частина респондентів підтримує участь у політичних демонстраціях, мітингах і пікетах як специфічну «професійну діяльність», яка повинна гарно оплачуватися. Тому громадян, «готових піти на політичні заходи заради винагороди вже достатньо багато і складає 69 \%» [8, с. 144]. У 2010 р. через скрутний матеріальний стан та «байдужого ставлення до усіх кандидатів» $24 \%$ опитаних громадян вважали можливим продати свій голос на гроші на виборах до органів влади [8, с. 148].

Наведені дані, як емпіричні індикатори поширення антидемократичних за своєю суттю гонорарних політичних практик, на думку вченого, є свідченням посилення «цинічного прагматизму» в поведінці різних груп населення України. «Найбільша чисельність прагматиків зосереджено: а) у молодіжній когорті; б) серед жителів центрального регіону країни; в) серед киян; г) серед осіб 3 початковим ступенем вищої освіти» [8, с. 150]. 


\section{СУПЕРЕЧНОСТІ ДЕМОКРАТИЧНОЇ МОДЕРНІЗАЦІЇ УКРАЇНСЬКОГО СУСПІЛЬСТВА ЯК ДЖЕРЕЛА ПОСИЛЕННЯ СОЦІАЛЬНОЇ НАПРУЖЕНОСТІ}

Вочевидь, що такі прагматичні настрої та поведінкові стратегії громадян, які виразно проявляються i в останній час, враховують різні політики та політичні сили при організації виборчих кампаній, розробляючи та застосовуючи різні технології «політичного туризму», прямого та опосередкованого підкупу виборців та скупки їх голосів. Проте важливо враховувати, що зазначені технології підкупу громадян є лише одним локальним аспектів поширеного в Україні феномену політичної корупції.

Важливість врахування даної обставини підкреслює О. Рудик, який вказує, що далеко не завжди політична корупція має чітко виражене матеріальне втілення або у вигляді конкретно обумовленого грошового еквівалента, або в обсязі певних послуг, що надаються. «Звичайно, й у сфері політичної корупції $є$ свої фіксовані ставки, але частка «твердих тарифів»є значно меншою. Деякі експерти взагалі говорять про відсутність монетарної сутності політичної корупції, оскільки винагорода використовується не в особистих цілях певної посадової особи, а у владно-політичних цілях (наприклад, підтримка керівництва під час політичних криз, або на виборах)» [7, с. 55].

Варто зазначити, що деякі науковці вчені вказують, політична корупція, яка відтворюється в Україні як латентне джерело соціальної напруженості, зумовлена посиленням процесів соціальної дезінтеграції українського суспільства. Так, А. Срмолаєв у статті «Національна держава і українське суспільство: зигзаг чи поворот» [2] наводить змістовну аргументацію, стосовно важливості подолання існуючої ситуації невизначеності політичної стратегії практичного вирішення, в умовах теперішнього багатоаспектного конфлікту 3 Росією, двох взаємопов'язаних фундаментальних проблем: 1) територіальної цілісності України та 2) їі соціальної цілісності [2, с. 3-5].

Проте на думку О. Рєзніка, політична корупція є важливим, однак не визначальним чинником соціальної напруженості. На основі узагальнення емпіричних даних репрезентативних соціологічних досліджень вчений робить наступний висновок: «Соціальна напруженість в українському суспільстві спричинюється переважно деприваційними та ресурсними чинниками» [6, с. 55].

Звісно, що даний висновок потребує певного уточнення та конкретизації в аспектах більш детального 3'ясування проявів каузальних детермінант дисфукціонального впливу певних типових соціальних явищ та процесів, які багатьма вченими ідентифікуються як сутнісні ознаки поняття «соціальна напруженість». Зазначимо, що незважаючи на те, що, дане поняття досі не має чітко визначеного пізнавального статусу [9, с. 2-5], все ж таки доцільно погодитися 3 позицією західних науковців, що сутнісні ознаки цього поняття загалом відображують типові ситуації: 1) поглиблення соціальних нерівностей (традиційних та нових); 2) зменшення долі середнього класу в соціальній структурі суспільства; 3) посилення соціальної бідності; 4) нестабільності 
розміру отриманих доходів; 5) обмеження соціальної мобільності; 6) активного використання антигуманних методів репресивно-насильницького соціального контролю з боку влади [11, с. 20-25; 10, с. 457-458].

Однак, на нашу думку, теперішня ситуація в Україні ускладнюється тим, що важливими перешкодами зниження рівня соціальної напруженості в українському суспільстві $€$ цілком реальна функціональність онтологічних чинників дезорганізації соціального порядку, які обумовлюють: 1) функціональність недовіри; 2 ф) функціональність корупції; 3) функціональність процесу депривації; 4) функціональність збройних конфліктів та терористичних акцій. Вочевидь, що подальше осмислення перспектив процесу демократизації передбачає організацію та проведення спеціалізованих наукових досліджень.

На основі запропонованої нами спроби дослідження суперечливого характеру політичних детермінант соціальної напруженості як спефічних джерел іiі посилення в українському суспільстві, можна зробити наступні висновки:

1. За основними параметрами своєї соціальної ідентифікації сучасне суспільство є пострадянським, демократична модернізація якого відбувається суперечливо, стихійно i непослідовно. Нинішня політична влада України підтримує консервативний сценарій демократичних перетворень, наслідком чого стало відтворення застарілих функціональних режимів політичної системи, внаслідок чого більшість громадян України знаходяться у стані амбівалентності по відношенню до політичних інститутів, легальність яких не підкріплена, ні правом ні мораллю.

2. Емпіричні дані репрезентативних моніторингових соціологічних досліджень засвідчують, що більшість населення по відношенню до процесу демократичних перетворень в Україні знаходиться у стані пасивності та не вірить у їх успіх. Саме тому в Україні сформувалися і стабільно відтворюються практики політичної участі громадян за матеріальну винагороду, тобто гонорарні політичні практики, які реально є соціальним джерелом політичної корупції. Поширеність політичної корупції у владних структурах України можна пояснити певними труднощами організації демократичного соціального порядку.

3. Важливими чинниками посилення соціальної напруженості в українському суспільстві є невизначеність політичної стратегії вирішення двох взаємопов'язаних фундаментальних проблем: 1) територіальної цілісності України та 2) їі соціальної цілісності. Існуюча глобальна конкуренція та реальна функціональність онтологічних чинників дезорганізації соціального порядку, таких як соціальна недовіра, корупція, депривація, збройні конфлікти та 


\section{СУПЕРЕЧНОСТІ ДЕМОКРАТИЧНОЇ МОДЕРНІЗАЦІЇ УКРАЇНСЬКОГО СУСПІЛЬСТВА ЯК ДЖЕРЕЛА ПОСИЛЕННЯ СОЦІАЛЬНОӤ НАПРУЖЕНОСТІ}

терористичні акції на даний час $€$ перешкодами консолідації сучасного українського суспільства.

\section{Список використаних джерел:}

1. Головаха Е. И. Украинское общество. Четверть века вынужденной трансформации и перспектива демократического транзита / Е. И. Головаха // Держава та соціальні зміни: 25 років української незалежності : матеріали VII міжнар. наук.-практ. конф. (Київ, 29-30 листоп. 2016 р.) / уклад.: А. А. Мельниченко, П. В. Кутуєв. - Київ ; Одеса : Айс Приват, 2016. - С. 15-17.

2. Ермолаев А. Национальное государство и украинское общество: зигзаг или поворот / А. Ермолаев // Украина: национальный транзит : сб. ин-та стратег. исслед. «Новая Украина». - Київ, 2017. - С. 2-11.

3. Михальченко М. І. Соціально-політична трансформація України: реальність, міфологеми, проблеми вибору / М. І. Михальченко, В. С. Журавський, В. В. Танчер. - Київ : Лотос, 1997. - 180 с.

4. Нові нерівності - нові конфлікти: шляхи подолання. III конгрес Соціологічної асоціації України : тези доп. (Харків, 12-13 жовт. 2017 р.). Харків : ХНУ ім. В. Н. Каразіна, 2017. - 516 с.

5. Проблеми розвитку соціологічної теорії: Структурні зміни та соціальна напруженість : матеріали XIV Міжнар. наук.-практ. конф., (Київ, 2526 трав. 2017 р.) / Київ. нац. ун-т ім. Т. Шевченка. - Київ : Логос, 2017 - 194 с.

6. Рєзнік О. Соціальна напруженість та масові протести в Україні: відмінність детармінант та механізми прояву / О. Рєзнік // Соціологія: теорія, методи, маркетинг. - 2017. - № 2. - С. 35-58.

7. Рудик О. Політична корупція в умовах демократії / О. Рудик // Українські діалоги. - 2015, листоп.-груд. - С. 54-57.

8. Шульга М. О. Дрейф на узбіччя. Двадцять років суспільних змін в Україні / М. О. Шульга. - Київ : Друкарня Бізнесполіграф, 2011 - 448 с.

9. Bouget D. Social Tension: some general elements / D. Bouget. - Oslo : The Peace Institute, 2008. - 36 p.

10. Lee Y. Measuring Social Tension from Income Class Segregation /Y. Lee, D. Shin // Journal of Business and Economic Statistics. - 2016. - Vol. 34, is. 3. pp. 457-471.

11. North D. C. Violence and Social Orders. A conceptrual framework for interpreting recorded human history / D. C. North, J. J. Wallisd, B. B. Waingast. New York : Cambrige univ. press, 2013. - 336 p.

\section{References:}

1. Golovakha, E.I. (2016). Ukrainian society. A quarter of a century of forced transformation and the prospect of democratic transit. V: State and Social Change: 
25 Years of Ukrainian Independence: materials of VIIth International scientific and practical conference, Ukraine, Kyiv, November 29-30, 2016. Kyiv; Odesa : Ais Pryvat, pp. 15-17.

2. Ermolaev, A. (2017). National state and Ukrainian society: zigzag or twis. Ukraina: natcionalnyi tranzit : sbornik instituta strategicheskikh issledovanii «Novaia Ukraina» [Ukraine: National Transit: The Collection of the Institute for Strategic Studies "New Ukraine"], pp. 2-11.

3. Mykhalchenko, M.I. (1997). Socio-political transformation of Ukraine: reality, mythological issues, problems of choice. Kyiv : Lotos.

4. New inequalities - new conflicts: ways to overcome. (2017). V: IIId Congress of Sociological Association of Ukraine: Theses. Ukraine, Kharkiv, October 12-13, 2017. Kharkiv : Kharkiv V.N. Karasin National University.

5. Problems of the development of sociological theory. (2017). V: Structural changes and social tension: materials of the XIVth International scientific and practical conference, Ukraine, Kyiv, May 25-26, 2017. Kyiv : Logos.

6. Rieznik, O. (2017). Social tension and mass protests in Ukraine: the difference between the precursor and the mechanisms of manifestation. Sotsiolohiia: teoriia, metody, marketynh [Sociology: theory, methods, marketing], no 2, pp. 35-58.

7. Rudyk, O. (2015). Political corruption in a democracy. Ukrainski dialohy [Ukrainian Dialogues], issue November-December, pp. 54-57.

8. Shulha, M.O. (2011). The drift to the side. Twenty years of social change in Ukraine. Kyiv : Biznespolihraf Print House.

9. Bouget, D. (2008). Social Tension: some general elements. Oslo : The Peace Institute.

10. Lee, Y. (2016). Measuring Social Tension from Income Class Segregation. Journal of Business and Economic Statistics, Vol. 34, issue 3, pp. 457-471.

11. North, D.C. (2013). Violence and Social Orders. A conceptrual framework for interpreting recorded human history. New York : Cambrige University Press.

( Судаков В. І., 2018 